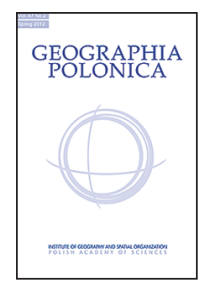

\title{
BIOCLIMATIC CONDITIONS OF THE LUBUSKIE VOIVODESHIP
}

\section{Agnieszka Mąkosza}

\author{
Institute of Technology and Life Science \\ West Pomeranian Research Center \\ Czesława 9, 71-504 Szczecin: Poland \\ e-mail: agnieszka_makosza@op.pl
}

\begin{abstract}
The objective of the present work is to present the temporal and spatial characteristics of the bioclimatic conditions of the Lubuskie Voivodeship. The daily timed values (12UTC) of meteorological elements in the period 1971-2006 from three stations (Słubice, Gorzów Wielkopolski and Zielona Góra) were used as the basis for the calculations. In order to assess the bioclimatic conditions, a thermal stress index UTCI (Universal Thermal Climate Index) that is calculated with the use of BioKlima 2.6 software was applied. The analysis shows that thermal stress related to 'slight and moderate cold stress' and 'no thermal stress' is a dominant factor $(80 \%)$ affecting the bioclimatic conditions of the Lubuskie Voivodeship. During the analysed period, days with thermal stress related to cold stress occurred more frequently than those with thermal stress related to heat stress. On the basis of a linear regression trend, a positive trend for thermoneutral conditions days and heat related stress days $\left(U T C l>32^{\circ} \mathrm{C}\right)$, as well as a negative trend for cold related stress $\left(U T C l<-13^{\circ}\right)$, were ascertained.
\end{abstract}

\section{Key words}

UTCI • bioclimatic conditions - stress category - Lubuskie Voivodeship • linear trend

\section{Introduction}

The diversified land relief of the Lubuskie Voivodeship is a consequence of its geographical location on the border of three sub-provinces (Południowobałtyckie Lake District, Środkowopolskie Lowlands, Sasko-Łużyckie Lowlands) (Kondracki 2000). In line with regionalisation provided by Kozłowska-Szczęsna et. al (1997), the territory of the Lubuskie Voivodeship is included in the bioclimatic region IV, specifically IVa, with weak stimuli. Such conditions can be regarded as favourable since weather conditions occurring in this region are not conducive to thermoregulatory system overload and do not limit recreational activities or tourism. As a result of its location in western Poland, in the Middle Odra Region, and the fact that it has various nature as well as cultural values, the Lubuskie Voivodeship promotes the development of tourism (Lijewski et. al. 2002; Gołembski 2009). Several rivers flow through the Lubuskie Voivodeship (Odra, Warta, Noteć, Nysa Łużycka). There are also several lakes, and those in the northern part of the region form the so-called 'Lubuskie Mazury', the second longest shipping lane in Poland, with a length of $75 \mathrm{~km}$ and a water table of over a thousand hectares. 50\% of this area is forested. It is one of the most forested territories in Poland with numerous National and Landscape Parks (Kijowski et al. 2005; Mąkosza 2009; UMWL 2012). Its physiographic features as well as substratum types, vegetation, hydrographic 
conditions, weather conditions and land use greatly affect the given area's bioclimate and its particular characteristics (Kozłowska-Szczęsna et al. 1997). As far as tourism and recreation are concerned, weather and climatic conditions are important nature values. The influence of the weather and climate on man is a complex issue, since it includes numerous physical conditions which change over time and space, and the physiological reactions of the human body when exposed to the stimuli of the atmospheric environment (Krawczyk 1995). Most case studies concerning bioclimatic conditions make use of compound indices that are based on human heat balance as regards the subjective thermal perception of a given organism. Recently, a new index - UTCI (Universal Thermal Climate Index) - has been developed (Błażejczyk et. al. 2010a, 2010b). It is based on a multi-node model of the human heat balance which considers heat transfer occurring in the human body and on its surface, and physiological thermoregulatory mechanisms. Data obtained with the use of UTCI constitute objective thermal stress values. It is valid to analyse bioclimatic conditions in this region of Poland since case studies concerning climatic conditions of this region, especially bioclimatic conditions, are relatively rare (Kalbarczyk \& Kalbarczyk 2008; Makosza 2009; Makosza \& Michalska $2010,2011)$. The results can be of use to local and administrative authorities of the voivodeship and provide insight and data which can be useful for promotion and tourism. The objective of this work is to present the temporal and spatial variability of UTCl and assess the bioclimatic conditions of the lakeland type area as confined to the administrative borders of the Lubuskie Voivodeship.

\section{Materials and methods}

Meteorological data was obtained from three weather stations located in the Lubuskie Voivodeship: Słubice, Gorzów Wielkopolski and Zielona Góra. The UTCI was calculated on the basis of meteorological elements such as daily timed (12 UTC) measurements of air temperature $\left({ }^{\circ} \mathrm{C}\right)$, relative humidity $(\%)$, wind speed $\left(\mathrm{m} \cdot \mathrm{s}^{-1}\right)$ and cloudiness (\%) for the period 1971-2006 and $\operatorname{Tmrt}\left({ }^{\circ} \mathrm{C}\right)$ - mean radiant temperature. Both mean radiant temperature (Tmrt) and UTCI were calculated with the use of the BioKlima 2.6 software package (Błażejczyk 2005). The assessment of bioclimatic conditions of Lubuskie Voivodeship was conducted using the thermal stress scale for UTCI calculated according to its study design and methodological assumptions (see articles in the current issue Błażejczyk et al. 2013; Bröde et al. 2013).

This paper includes mean, maximum and minimum UTCl values in the annual, monthly and daily course together with the analysis of the linear regression trend. Frequency of respective thermal stress in subsequent months and days of a year was characterized and compared according to the UTCl range. Periods with extreme biothermal conditions $\left(\mathrm{UTCl}<-13^{\circ} \mathrm{C}\right.$ and $\left.\mathrm{UTCl}>32^{\circ} \mathrm{C}\right)$ and thermoneutral conditions (UTCl from 9 to $26^{\circ} \mathrm{C}$ ) were determined and compared as given by stations. The variability noted over many years and the linear regression trend for individual ranges of thermal stress were presented. The statistical significance of the correlation coefficient was estimated as based on $\alpha=0.05$ and $\alpha=0.01$.

\section{Results}

In the period 1971-2006, mean annual values of UTCI on the area of Lubuskie Voivodeship fluctuated from $6.1^{\circ} \mathrm{C}$ in Zielona Góra and Gorzów Wielkopolski to $8.8^{\circ} \mathrm{C}$ in Słubice. In the annual course, the highest mean values occur interchangeably (according to the year) in July and September, with slightly higher mean values reaching approx. $23^{\circ} \mathrm{C} \mathrm{UTCl}$ observed in Słubice. In turn, the lowest mean UTCl values usually occur in January, mostly in Gorzów Wielkopolski and Zielona Góra, reaching almost $-10^{\circ} \mathrm{C} \mathrm{UTCl}$ (Tab. 1). A similar range of UTCl values (from -13 to $24^{\circ} \mathrm{C}$ ) for the period 2000-2009 for Warsaw was obtained by Lindner (2011).

On the basis of the obtained results it was found that in the hours around midday in the period 1971-2006 there were no UTCI values exceeding $46^{\circ} \mathrm{C}$, which would cause thermal stress that is categorized as 'extreme heat stress'. The highest calculated UTCI values in the Lubuskie Voivodeship in that period occurred on August 9, 1992 and were: Słubice $43.1^{\circ} \mathrm{C}$, Gorzów Wielkopolski $41.9^{\circ} \mathrm{C}$, Zielona Góra $40.4^{\circ} \mathrm{C}$. The aforementioned values are slightly higher than those obtained in Warsaw (June 22, 2000) by Lindner (2011) and are comparable to those calculated for Łódź by Błażejczyk and Kunert (2010). The high UTC/ value on that day was influenced by weather conditions in the whole territory of the voivodeship, since the measured air temperature was from $35.8^{\circ} \mathrm{C}$ in Zielona Góra to $37.3^{\circ} \mathrm{C}$ in Stubice, with rela- 
tively low air humidity (24-28\%), low wind speed $\left(0-2 m \cdot s^{-1}\right)$ and a relatively cloudless sky - only in Zielona Góra was the sky coverage at the level 1 octant. Conversely, absolutely the lowest UTCl value of $-54.8^{\circ} \mathrm{C}$ was noted in Gorzów Wielkopolski on December 31, 1978, which corresponds with the highest thermal stress exceeding $-40^{\circ} \mathrm{C}$ UTCl that is labelled as 'extreme cold stress' in the adopted classification. In Słubice and Zielona Góra the minimum values were lower, $-42.9^{\circ} \mathrm{C}$ (December 31, 1978) and $-40.8^{\circ} \mathrm{C}$ (January 1, 1979) respectively, yet thermal stress still falls within the 'extreme cold stress' classification (Tab. 1). The absolute minimum values noted at 12 UTC in Słubice and Zielona Góra correspond with those calculated for Warsaw and Łódź. However, it should be observed that in the two locations (Słubice and Zielona Góra), the 'extreme cold stress' was reported only once during the period analysed on the aforementioned days, and in Gorzów Wielkopolski there were 6 days with 'extreme cold stress' during a period of 36 years, mainly in late 1970s and early 1980s.

Absolute maximum and minimum UTCl values in the hours around midday show a positive trend, which is statistically significant only in case of minimum values ( $\alpha=0.05$ for Zielona Góra, $\alpha=0.01$ for Słubice and Gorzów Wielkopolski). Absolute annual amplitudes of UTCI values fluctuate from $52.4^{\circ} \mathrm{C}$ (Słubice 2004) to $88.4^{\circ} \mathrm{C}$ (Gorzów

Table 1. Average, maximum, minimum and amplitude of UTCl values at 12 UTC. Year 1971-2006.

\begin{tabular}{|c|c|c|c|c|c|c|c|c|c|c|c|c|c|}
\hline Months & 1 & ॥ & III & IV & V & $\mathrm{VI}$ & VII & VIII & IX & $x$ & $X I$ & XII & Year \\
\hline \multicolumn{14}{|c|}{ Average } \\
\hline$S$ & -6.5 & -3.6 & 1.1 & 8.6 & 16.8 & 19.8 & 22.5 & 22.7 & 17.2 & 10.6 & 0.4 & -4.6 & 8.8 \\
\hline GW & -9.5 & -6.9 & -2.1 & 5.8 & 15.0 & 17.9 & 21.0 & 21.2 & 14.7 & 7.3 & -3.2 & -8.0 & 6.1 \\
\hline ZG & -9.7 & -6.7 & -1.6 & 6.3 & 14.8 & 17.7 & 20.5 & 20.8 & 14.7 & 7.6 & -2.9 & -8.5 & 6.1 \\
\hline \multicolumn{14}{|c|}{ Maximum } \\
\hline$S$ & 8.3 & 13.8 & 19.3 & 25.7 & 31.2 & 34.9 & 36.8 & 36.2 & 30.9 & 25.0 & 15.3 & 8.9 & 23.9 \\
\hline GW & 6.8 & 10.3 & 17.7 & 23.7 & 30.2 & 33.6 & 36.0 & 35.0 & 29.5 & 23.0 & 12.6 & 6.7 & 22.1 \\
\hline ZG & 6.0 & 10.9 & 17.1 & 23.9 & 29.4 & 33.5 & 35.2 & 34.6 & 29.4 & 23.0 & 13.5 & 4.9 & 21.8 \\
\hline \multicolumn{14}{|c|}{ Minimum } \\
\hline$S$ & -25.6 & -22.1 & -16.5 & -11.7 & -1.0 & 3.7 & 6.9 & 7.0 & 3.3 & $\begin{array}{l}-5.7 \\
\end{array}$ & -17.7 & -21.7 & -8.4 \\
\hline GW & -29.2 & -29.2 & -20.3 & -16.1 & -4.4 & 1.6 & 4.5 & 4.9 & -0.7 & -9.4 & -20.9 & -28.8 & -12.3 \\
\hline ZG & -27.0 & -24.3 & -18.4 & -13.6 & -2.1 & 2.0 & 5.3 & 4.5 & 0.6 & -8.6 & -19.6 & -25.3 & -10.5 \\
\hline \multicolumn{14}{|c|}{ Amplitude } \\
\hline$S$ & 33.9 & 35.9 & 35.8 & 37.4 & 32.2 & 31.2 & 29.9 & 29.2 & 27.6 & 30.7 & 32.9 & 30.6 & 32.3 \\
\hline GW & 36.0 & 39.5 & 38.0 & 39.8 & 34.6 & 32.1 & 31.4 & 30.1 & 30.2 & 32.3 & 33.5 & 35.5 & 34.4 \\
\hline ZG & 33.0 & 35.2 & 35.5 & 37.4 & 31.4 & 31.5 & 29.9 & 30.1 & 28.8 & 31.6 & 33.1 & 30.2 & 32.3 \\
\hline \multicolumn{14}{|c|}{ Absolute maximum } \\
\hline S & 13.7 & 19.9 & 24.6 & 31.9 & 36.4 & 39.7 & 42.2 & 43.1 & 34.5 & 31.1 & 19.7 & 13.9 & 43.1 \\
\hline GW & 11.1 & 17.9 & 23.4 & 31.4 & 35.1 & 38.8 & 41.6 & 41.9 & 35.3 & 30.0 & 21.1 & 13.4 & 41.9 \\
\hline ZG & 10.2 & 16.5 & 25.0 & 30.8 & 34.2 & 37.7 & 39.7 & 40.4 & 35.4 & 29.3 & 21.2 & 12.3 & 40.4 \\
\hline \multicolumn{14}{|c|}{ Absolute minimum } \\
\hline$S$ & -38.3 & -34.3 & -33.6 & -21.5 & -11.1 & -5.2 & 1.7 & -1.2 & -1.9 & -15.9 & -25.1 & -42.9 & -42.9 \\
\hline GW & -41.7 & -41.0 & -31.7 & -29.2 & -15.2 & -3.3 & -3.3 & -5.0 & -6.1 & -21.2 & -33.1 & -54.8 & -54.8 \\
\hline ZG & -40.8 & -31.0 & -30.7 & -22.4 & -9.4 & -1.5 & -1.9 & -1.7 & -5.0 & -17.2 & -29.5 & -36.0 & -40.8 \\
\hline \multicolumn{14}{|c|}{ Absolute amplitude } \\
\hline$S$ & 51.9 & 54.2 & 58.3 & 53.5 & 47.5 & 44.8 & 40.6 & 44.3 & 36.4 & 46.9 & 44.8 & 56.8 & 86.0 \\
\hline GW & 52.8 & 58.9 & 55.0 & 60.6 & 50.3 & 42.1 & 44.8 & 46.8 & 41.4 & 51.2 & 54.2 & 68.2 & 96.7 \\
\hline ZG & 51.0 & 47.4 & 55.7 & 53.2 & 43.6 & 39.2 & 41.6 & 42.0 & 40.4 & 46.5 & 50.6 & 48.3 & 81.2 \\
\hline
\end{tabular}

S - Słubice, GW - Gorzów Wielkopolski, ZG - Zielona Góra 
Wielkopolski 1978) and in the whole voivodeship present a negative trend. Slightly higher amplitudes of UTCI values were reported in the cold half-year period than in the warm half-year period. In Słubice and Zielona Góra the highest absolute amplitudes occur in March, and in Gorzów Wielkopolski in December. The lowest amplitudes were reported in September in Słubice and Gorzów Wielkopolski and in June in Zielona Góra (Tab. 1 and Fig. 1).

Throughout the whole territory of Lubuskie Voivodeship, a statistically significant positive trend of mean values was observed. Linear trend analysis for individual months shows a positive trend for mean values in almost every month (statistically significant for the whole area in April and November, and for Gorzów Wielkopolski also in October (Fig. 2). A slightly negative trend (with no statistical significance) for mean UTCl values was observed in Gorzów Wielkopolski only in September and in Zielona Góra in September and February.

The next stage of this case study is devoted to frequency of UTCI values within the range of UTCI thermal stress assessment scale (Fig. 3, 4 and 5). It was reported that over the course of a year, days with weather conditions which do not cause thermal stress occur more often, and UTCl values are in the range from 9 to $26^{\circ} \mathrm{C}$. The frequency of such days in the Lubuskie Voivodeship is 36\%
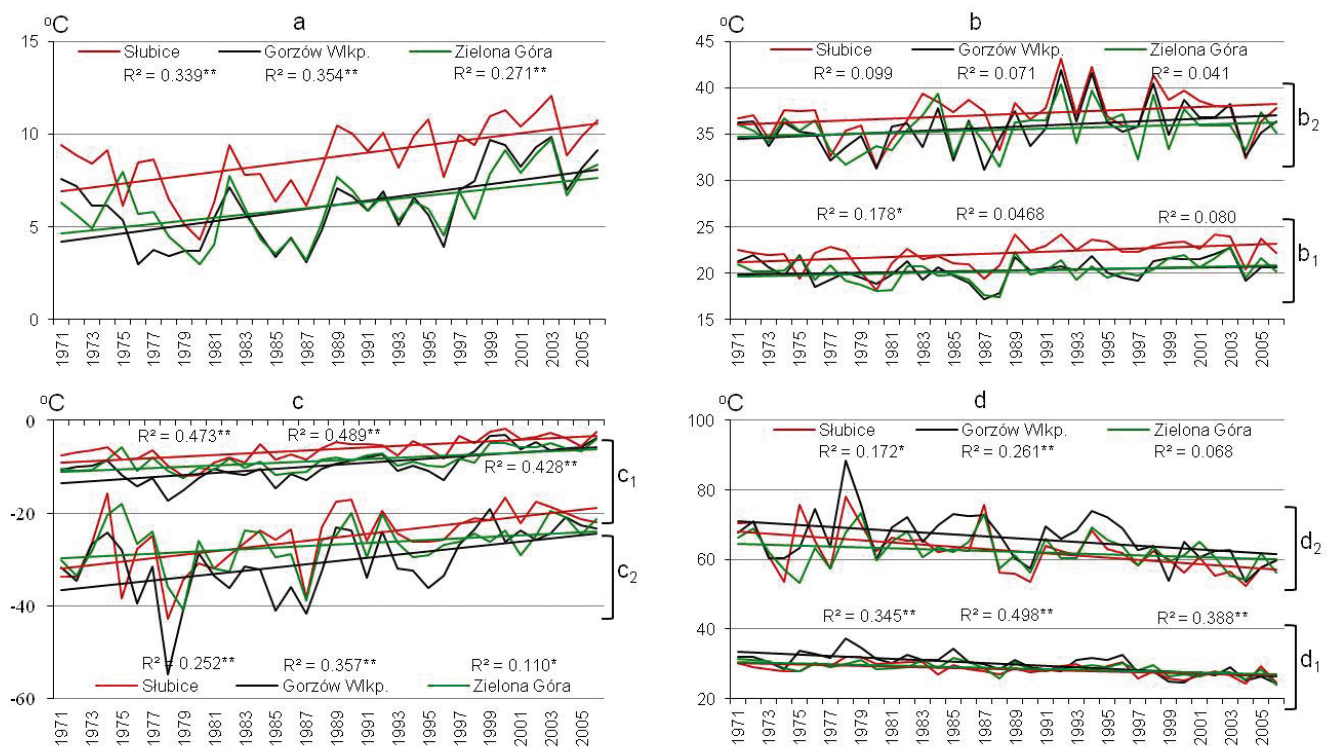

Figure 1. Variability of average (a), maximum $\left(b_{1}\right)$, minimum $\left(c_{1}\right)$ amplitude $\left(d_{1}\right)$ and absolute maximum $\left(b_{2}\right)$, minimum $\left(c_{2}\right)$ and amplitude $\left(d_{2}\right)$ of UTCl index at 12 UTC during 1971-2006 with linear trend.

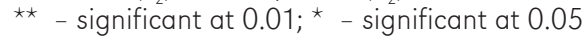
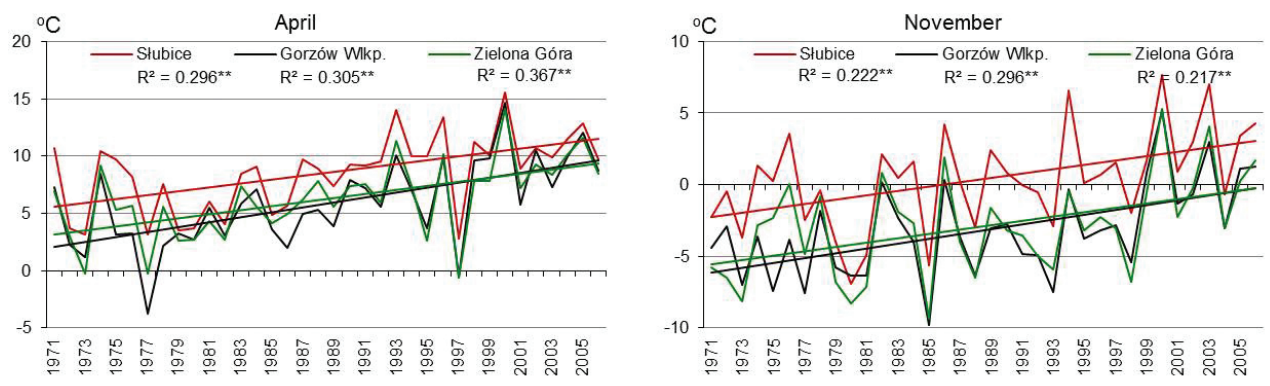

Figure 2. Variability of average value of UTCI index at 12 UTC in the area of the Lubuskie Voivodeship with trend in the chosen months (April and November) during 1971-2006.

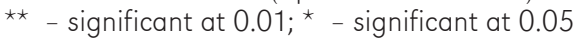




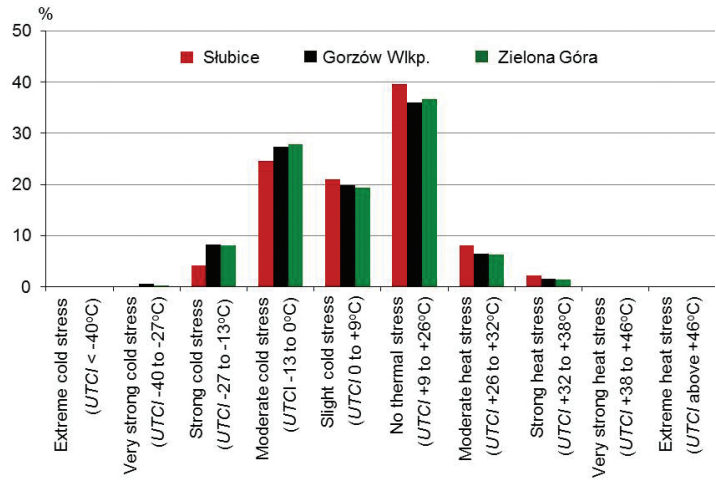

Figure 3. The frequency of thermal stress categories according to UTCI at 12 UTC in the Lubuskie Voivodeship. Year 1971-2006.
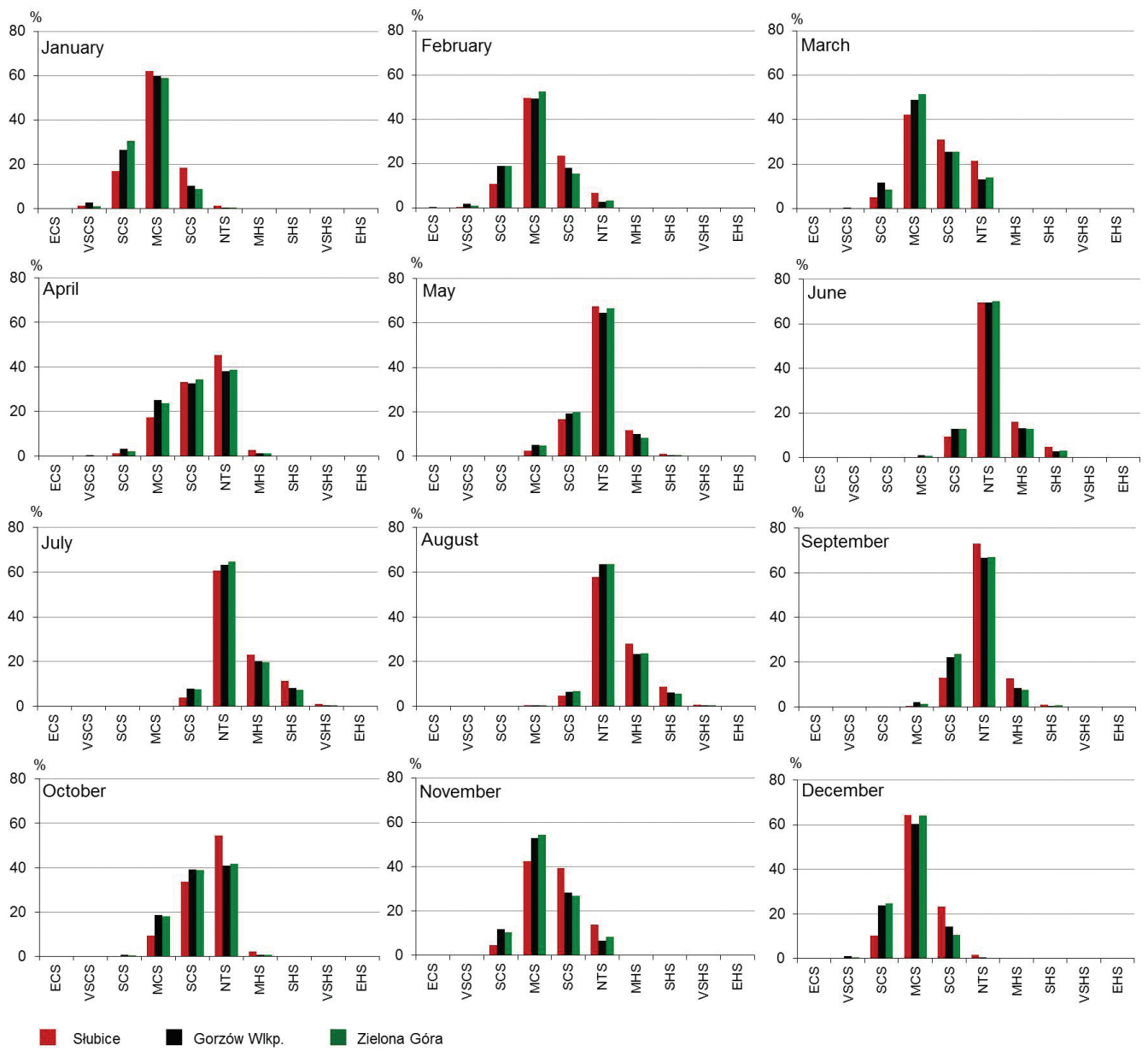

Figure 4. The frequency of thermal stress categories according to UTCI at 12 UTC in following months. Year 1971-2006. ECS - extreme cold stress; VSCS - very strong cold stress; SCS - strong cold stress; MCS - moderate cold stress; SCS - slight cold stress; NTS - no thermal stress; MHS - moderate heat stress; SHS - strong heat stress; VSHS - very strong heat stress; EHS - extreme heat stress. 

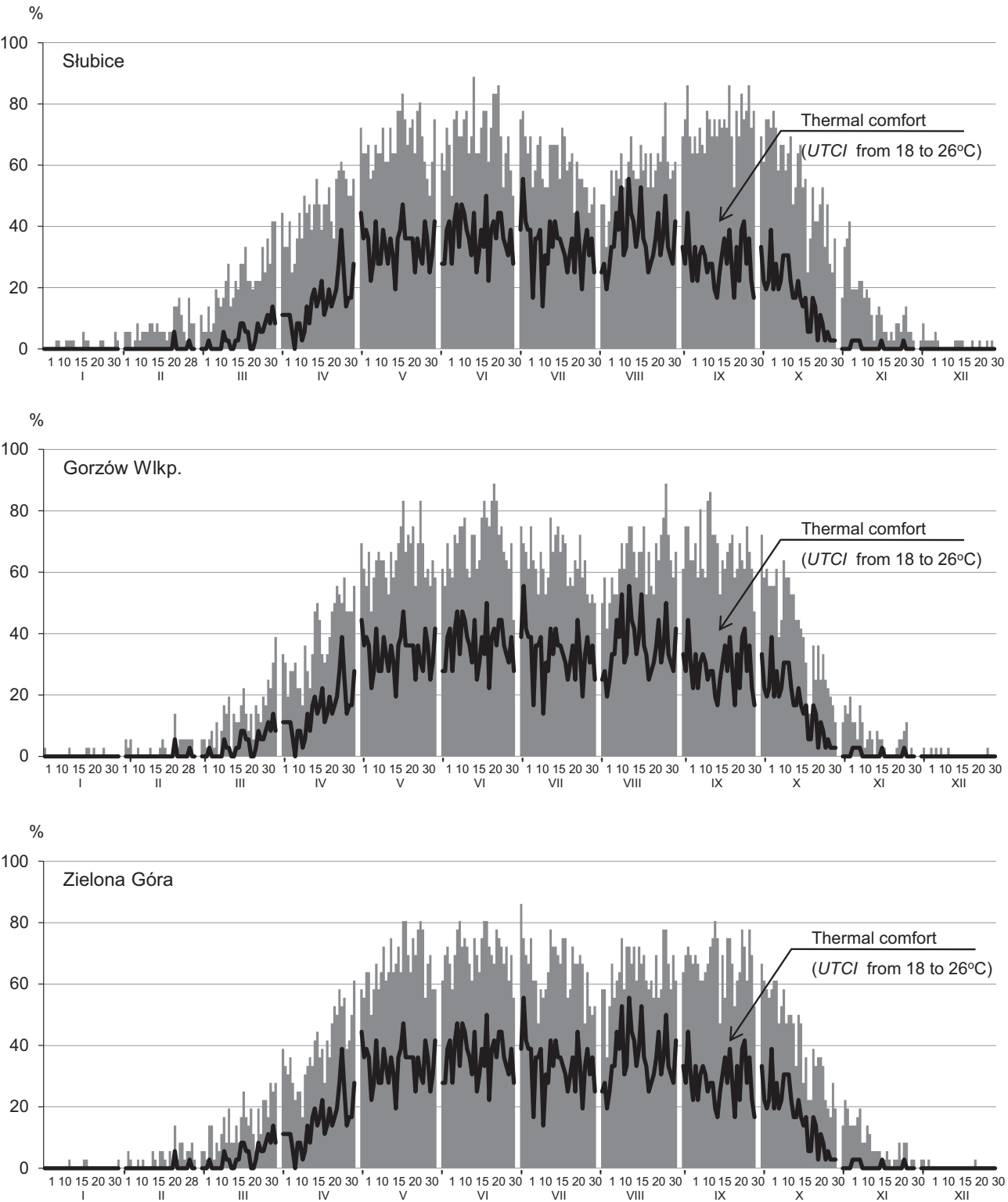

Figure 5. The frequency of 'no thermal stress' and thermal comfort (according to UTCl index at 12 UTC) in the following days of the year on the area of the Lubuskie Voivodeship. Year 1971-2006.

(Gorzów Wielkopolski) - 40\% (Słubice), which is on average from 130 to 145 days in a year. The highest frequency of days with 'no thermal stress' is observed from April to October, and a frequency of over $50 \%$ is reported since the beginning of May until the last but one pentad of July, and since the second pentad of August until the end of the second pentad of October in Zielona Góra, and a bit longer in Gorzów Wielkopolski - until the end of the third pentad, and until the end of the fourth pentad in Słubice. Frequency of days with UTCl between 18 and $26^{\circ} \mathrm{C}$ was calculated, which according to the Glossary of Terms for Thermal Physiology (IUPS 2003) fully conforms with the definition of the thermal comfort zone. Mean annual figures within the thermal comfort zone on the territory of the voivodeship fluctuate from 63 in Słubice to 54 in Zielona Góra. They show great variability from one year to another and can be within the range of 40 to 90 . The highest 

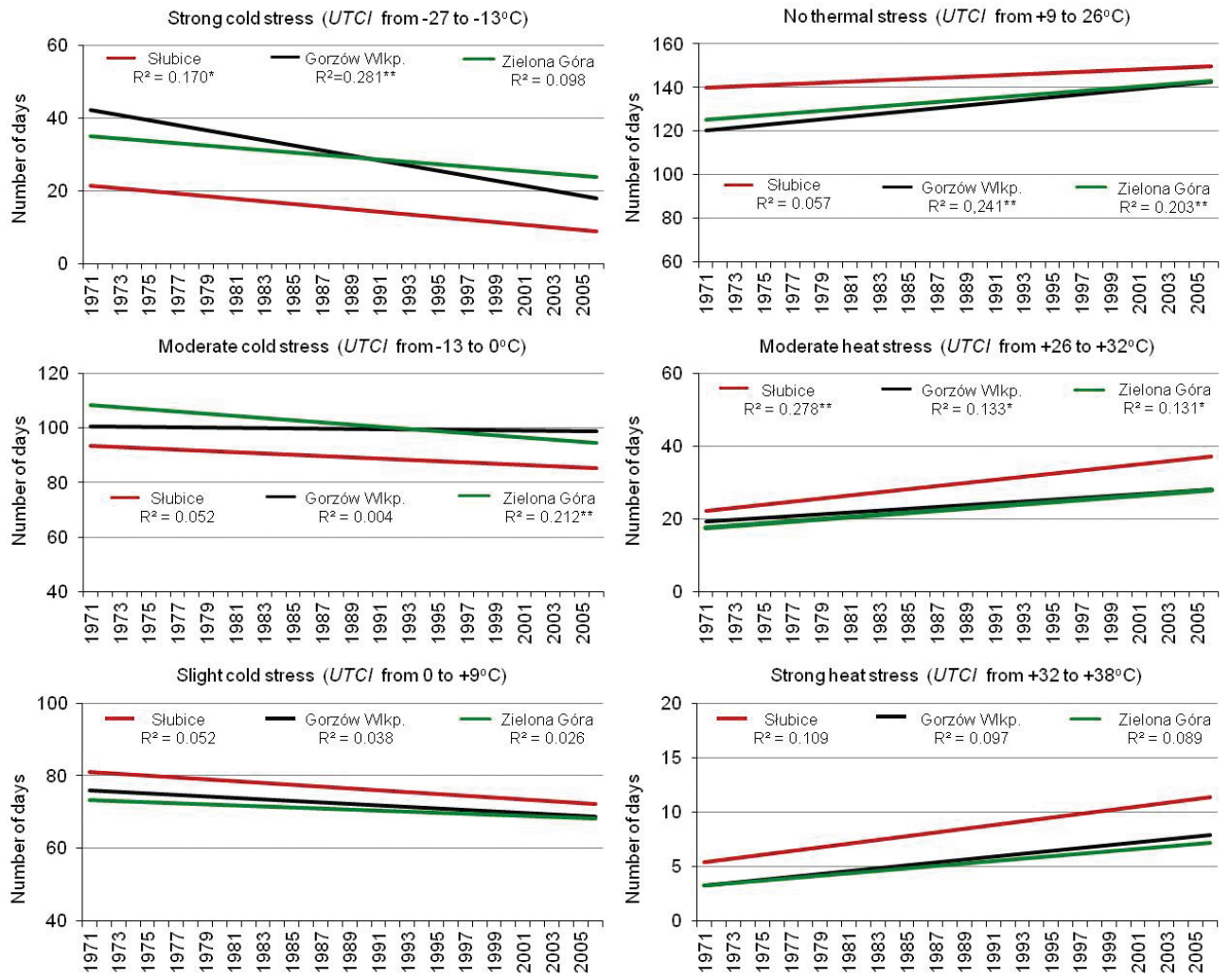

Figure 6. Trend number of days in selected stress categories according to UTCl index. Year 1971-2006. ** - significant at $0.01{ }^{\star}{ }^{\star}$ - significant at 0.05

frequency is observed from May to August with maximum occurrence in Gorzów Wielkopolski and Zielona Góra in August and in Słubice in June and August (Fig. 5). The number of days with UTCl values within that range can be seen as a statistically significant positive trend. Just over $25 \%$ of days in a year are of the 'moderate cold stress' type. Those days are marginally more common in southern part of the Lubuskie Voivodeship. In practice, this type of cold stress does not occur from June to August, although there were instances when this took place over a period of 36 years: on July 9, 1996 the UTCl value in Gorzów Wielkopolski was $-3.3^{\circ} \mathrm{C}$. 'Slight cold stress' is the third most frequent, and can be spatially organized inversely to the days in which they are more common in the north of the voivodeship. To sum up, there are three UTCl categories which predominantly shape ( $80 \%$ of days) bioclimatic conditions in the Lubuskie Voivodeship: 'slight cold stress', 'moderate cold stress' and 'no thermal stress'. Thermal stress connected with 'strong cold stress' occurs from November to April, with a maximum in January. Days with 'strong heat stress' are rare in the Lubuskie Voivodeship; they occur mainly in July and August, but also in June and some days in May and September. Occasionally in the hours around midday, there are days in which the thermal stress can be categorized as 'very strong cold and heat stress'.

In the period 1971-2006 a linear trend for other UTCl stress categories was analysed (Fig. 6). It was found that the trend of days with categories related to cold stress was negative. In the case of 'very strong cold stress', there is a highly significant relationship in Słubice and one that is significant in Gorzów Wielkopolski. On the other hand, the significance of the 'strong cold stress' category is different: a trend observed in Gorzów Wielkopolski is highly significant and one that has been observed in Słubice is significant. The analysis of the UTCl range constituting 'moderate cold stress' shows a statistically highly significant relationship only in Zielona Góra. In terms of the 

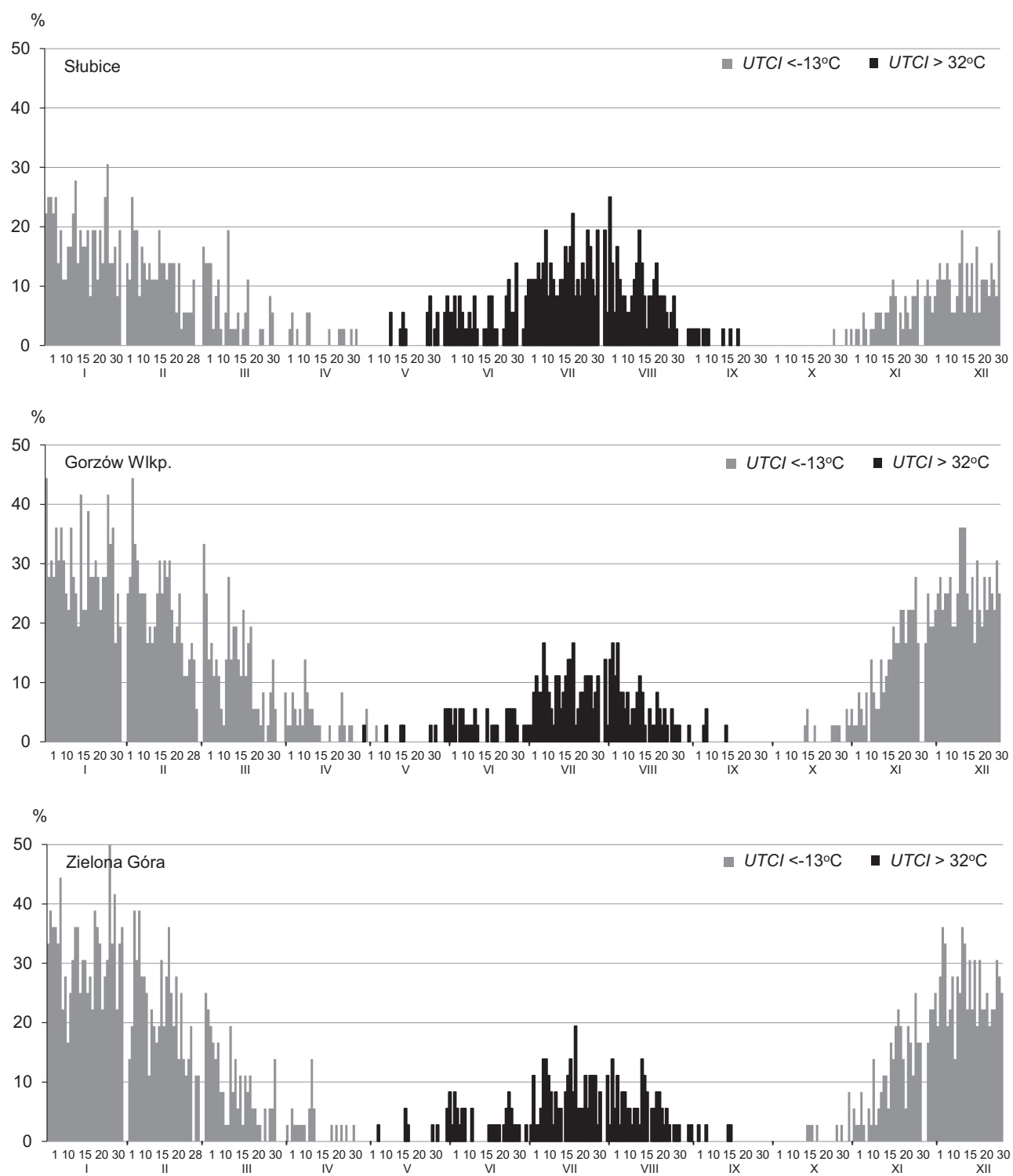

Figure 7. The frequency of UTCI values below $-13^{\circ} \mathrm{C}$ and above $32^{\circ} \mathrm{C}$ in the following days of the year on the area of the Lubuskie Voivodeship.

variability of the annual number of days with 'slight cold stress', only a downward trend was observed on the territory of the Lubuskie Voivodeship. As far as thermal changes in an organism are concerned, the most optimal category - 'no thermal stress' - represents an upward trend of those days in a year on the whole territory of the voivodeship, though a highly significant trend was noted only in Gorzów Wielkopolski and Zielona Góra. In the case of categories connected with heat stress, an explicit increase in the annual number of days in subsequent years is observed. This increase is most visible in Słubice, where a statistically highly significant linear trend for 'moderate heat stress' category was reported. An increase in the number of days in the 'moderate heat stress' category in Gorzów Wielkopolski and Zielona Góra is also statistically significant.

The fact that extreme values of the analysed index occurred frequently shows that the area has highly specific bioclimatic conditions (Błażejczyk $\&$ Kunert 2010). Having summed up the annual 
number of days with stress of values $U T C K-13^{\circ} \mathrm{C}$ and $U T C />32^{\circ} \mathrm{C}$, it was revealed that on average there were twice as many days with $\mathrm{UTCl}<-13^{\circ} \mathrm{C}$ annually in Zielona Góra (32 days) or Gorzów Wielkopolski (30 days) than in Słubice (16 days). In turn, days with UTCl $>32^{\circ} \mathrm{C}$ were more frequent in Słubice ( 9 days) than in other locations in the voivodeship (Fig. 7).

\section{Conclusions}

According to Lijewski et al. 2002 the period in which people enjoy recreational and natural values in Poland lasts from the 1st decade of May to the 1st decade of October. This coincides with conditions that have the least thermal stress on man in the Lubuskie Voivodeship. A positive trend in the number of days with no thermal stress can indicate a lengthening of this period in midwestern Poland, especially in Słubice and Zielona Góra. According to regionalisation provided by Kozłowska-Szczęsna et al. (1997), the Lubuskie Voivodeship is categorised as a part of bioclimatic region with weak stimuli. A small number of days with extreme UTCI values and a large number of days with no thermal stress (more than 30-40\%) reflect the general bioclimatic features of this region of Poland. Favourable weather conditions, geographical and natural environment values (forests, lakes) create surroundings perfectly fit for recreational activities. Although the number of days without thermal stress is predominant in the

\section{References}

BŁAŻEJCZYK K., 2005. BIOKLIMA software MENEX. Website: http://www.igipz.pan.pl/tl_files/igipz/ZGiK/opracowania/indywidualne/blazejczyk/MENEX_2005. pdf [10 January 2012].

BŁażejczyk K., Bröde P., Fiala D., Havenith G., Holmér I., Jendritzky G., KampmanN B., 2010a. UTCl - Nowe narzędzie badań warunków bioklimatycznych w różnych skalach czasowych i przestrzennych. Przegląd Geofizyczny, vol. 55, no. 1-2. pp. 5-19.

BŁażejczyk K., Bröde P., fiala D., Havenith G., Holmér I., Jendritzky G., Kampmann B., Kunert A., 2010b. Principles of the new Universal Thermal Climate Index (UTCI) and its application to bioclimatic
Lubuskie Voivodeship, it is possible to distinguish Lubuski Przełom Odry Mesoregion, represented in this paper by Słubice, which in comparison to the rest of the area has a distinctively greater number of onerous days with heat stress. The same applies to the Zielonogórskie Elevation (Zielona Góra) where the number of days with stress related to cold is slightly higher. However, extreme UTCl values of thermal stress connected with cold stress were most frequent in Gorzów Wielkopolski. Summing up, the study revealed that bioclimatic conditions on the area of the Lubuskie Voivodeship are primarily determined ( $80 \%$ ) by thermal stress related to 'slight' and 'moderate cold stress', and to 'no thermal stress'. Days with thermal stress related to cold stress were more common in the analysed period than days with heat stress - 50-55\% and $8-11 \%$ respectively. A positive trend of days with thermoneutral conditions and UTCI values $>32^{\circ} \mathrm{C}$ (heat stress category) and a negative trend for $U T C K<-13^{\circ} \mathrm{C}$ (cold stress category) were reported.

\section{Acknowledgements}

The study was partially financed by the Polish Ministry of Science and Higher Education - research promotorship project - N N306 066934

Editors' note:

Unless otherwise stated, the sources of tables and figures are the author(s), on the basis of their own research.

research in European scale. Miscellanea Geographica, vol. 14, pp. 91-102.

BŁażEJCZYK K., Jendritzky G., Bröde P., Fiala D., Havenith G., Epstein Y., Psikuta A., Kampmann B., 2013. An Introduction to the Universal Thermal Climate Index (UTCI). Geographia Polonica, vol. 86, iss. 1, pp. 5-10.

BŁAŻEJCZYK K., Kunert A., 2010. Warunki bioklimatyczne wybranych aglomeracji Europy i Polski. [in:] E. Bednorz, L. Kolendowicz (eds.), Klimat Polski na tle klimatu Europy. Zmiany i konsekwencje, Studia i Prace z Geografii i Geologii, no. 16, Poznań: Bogucki Wydawnictwo Naukowe, pp. 93-106.

Bröde P., Krüger E. L., Fiala D., 2013. UTCl validation and practical application to the assessment of urban 
outdoor thermal comfort. Geographia Polonica, vol. 86 , iss. 1 , pp. 11-20.

GoŁembSkı G. (ed.), 2009. Kompendium wiedzy o turystyce. Warszawa: Wydawnictwo Naukowe PWN, 450 pp.

IUPS, 2003. Glossary of terms for thermal physiology. Third Edition revised by The Commission for Thermal Physiology of the International Union of Physiological Sciences. Journal of Thermal Biology, vol. 28, no. 1, pp. 75-106.

Kalbarczyk E., Kalbarczyk R., 2008. Klimatyczne warunki rozwoju turystyki w województwie lubuskim i ich zmienność na przełomie XX i XXI wieku. [in:] S. Bosiacki (ed.), Gospodarka turystyczna w XXI wieku: problemy i perspektywy rozwoju w skali regionalnej i lokalnej, Poznań: Akademia Wychowania Fizycznego w Poznaniu, pp. 289-299.

KıJowski A., KıJowska J., Kozacki L., Mania W. (eds.), 2005. Środowisko przyrodnicze Ziemi Lubuskiej - wybrane zagadnienia. Poznań: Oficyna, 226 pp.

Kondracki J., 2000. Geografia regionalna Polski. Warszawa: Wydawnictwo Naukowe PWN, 440 pp.

KozŁowska-SzCZęsnA T., BŁAŻEJCZYK K., KrawczYK B., 1997. Bioklimatologia człowieka. Metody i ich zastosowania w badaniach bioklimatu Polski. Monografie, vol. 1, Warszawa: Instytut Geografii i Przestrzennego Zagospodarowania PAN, 200 pp.

KRAWCZYK B., 1995. Bioklimat Polski a możliwość klimatoterapii, wypoczynku i pracy na wolnym powietrzu. Przegląd Geograficzny, vol. 67, no. 1-2, pp. 29-43.

LIJewski T., MikuŁowski B., Wyrzykowski J., 2002. Geografia turystyki Polski. Warszawa: Polskie Wydawnictwo Ekonomiczne, 378 pp.
LINDNER K., 2011. Assessment of sensible climate in Warsaw using UTCl. Uniwersytet Warszawski. Prace i Studia Geograficzne, vol. 47, Warszawa: Wydział Geografii i Studiów Regionalnych, Uniwersytet Warszawski, pp. 285-291.

Mąkosza A., 2009. Warunki bioklimatyczne Pojezierza Wielkopolskiego dla potrzeb rekreacji, turystyki iagroturystyki. Unpublished Ph.D. thesis, Szczecin: Zachodniopomorski Uniwersytet Technologiczny w Szczecinie, Zakład Meteorologii i Klimatologii [typescript].

Mąkosza A., Michalska B., 2010. Ocena warunków biotermicznych w Polsce środkowozachodniej na podstawie temperatury odczuwalnej (STI). Folia Pomeranae Universitatis Technologiae Stetinensis. Argicultura, Alimentaria, Piscaria et Zootechnica, vol. 279 (15), pp. 53-62.

Mąikosza A., Michalska B., 2011. Występowanie stresu ciepła w środkowo-zachodniej Polsce. Prace i Studia Geograficzne, vol. 47, Warszawa: Wydział Geografii i Studiów Regionalnych. Uniwersytet Warszawski, pp. 265-274.

UMWL, 2012. Plan Zagospodarowania Przestrzennego Województwa Lubuskiego. Część I: Uwarunkowania rozwoju przestrzennego województwa lubuskiego. Koncepcja rozwoju regionu. Zielona Góra: Urząd Marszałkowski Województwa Lubuskiego, 460 pp. http://www.biplubuskie.pl/index. php?page=alias-7 [8 February 2012] . 